DOI: http://dx.doi.org/10.26858/est.v1i1.6271

\title{
The Effectiveness of Students Helping Students Technique In Improving Learners' English Grammar
}

\author{
Muhammad Rafiq ${ }^{1}$, Sukmawaty ${ }^{2}$ \\ ${ }^{1}$ Pendidikan Bahasa Inggris, Akademi Maritim Indonesia AIPI Makassar, Indonesia \\ Email: muhamadrafiq.mr@gmail.com \\ ${ }^{2}$ Universitas Hasanuddin Makassar, Indonesia \\ Email: sukmawaty@gmail.com
}

(Received: October-2018; Reviewed: October-2018;; Accepted: December-2018; Published: December-2018) access under license CC BY-NC-4.0 (https://creativecommons.org/licenses/by-nc/4.0/ ).

\begin{abstract}
This research was carried out at STIKES Panakkukang Makassar. The aims of the study were to assess the use of students helping students technique in assessing students' grammar achievement. The objects of the study were 42 students in second semester of nursing department. The students were divided into two groups, 22 students were in experimental group and 20 students were in control group. The research employed a quasi-experimental with experimental and control group. In the experimental group, students helping students technique was used for grammar activities, while traditional grouping technique was employed in control group. The data were obtained from grammar test with pre-test, and post-test. The result of this research indicated that the uses of Cooperative Learning of Students helping Students technique in students' grammar achievement were improved more significantly than the traditional grouping technique. The result of independent sample t-test indicated that t-observed value 3.272 was higher than t-table value 2.021 .
\end{abstract}

Keywords: Students Helping Students Technique; Students' Grammar Achievement

\section{INTRODUCTION}

As one of English components in English language learning, grammar is generally focused on a lot of educational field. Grammar is "the term that teachers and learners use to refer to the way that language is organized, it based on collection of rules which are used to create words and sentences" (Schellekens, 2007). Besides that, grammar is also the study of words and how they can be used in a sentence. The less understanding of grammar usage will affect the learners to have difficulties in writing or speaking correctly.

Subasini \& Kokilavani (2013), stated that It is really important to use correct grammar to help the listener understand easily and to avoid the misunderstanding.

To make students become active, teachers should apply the appropriate methods or techniques in the teaching and learning process, because the appropriate technique is one of the elements that have to be considered by the teacher to reach the students' learning outcome or students' success in their learning.

Cooperative Learning is an "arrangement where students work in mixed ability groups and are rewarded on the basis of the success of the group" not the success of individual (Woolfook, 2010). There are five 
elements of Cooperative learning: Face to face interaction, Positive independence, Individual accountability, Group processing and Collaborative skills.

Cooperative Learning consists of some Techniques that have been used in many varieties of subjects: Cooperative Integrated Reading and Composition (CIRC) (Slavin, 1994). Jigsaw designed by (Aronson, 2011), then (Slavin, 1994), developed a modification of Jigsaw which is known as Jigsaw II, Group Investigation (Sharan \& Sharan, 1992), Learning Together developed by (Johnson \& Johnson, 1987) and Students Teams Achievement Division (STAD) by (Slavin, 1994).

Students Teams Achievement Division (STAD) is one of Cooperative learning technique where students are appointed to fourmember learning that consists of various students' performance level, gender, and ethnicity. The teacher explains the lesson, and then students work with their teams to make sure that all the members of the team have understood the lesson. At the end, all students will do individual assessment on the material, at that time they may not help one another (Slavin, 1994).

However, Johnson \& Johnson (1994), points out that it is not enough just set the students in the group and tell them to work together for CL. Cooperative learning needs more than simply seating around a table and assigning them to share and to be nice to one another. When the students are set equally the same in the class, the debating among the students will not be

avoided, the students who have basic knowledge about the material will dominate the group while the students who have no such knowledge will not be active. Therefore, a leader in a team is needed to guide the group members in achieving the group tasks.

Based on Johnson's opinion above, the writer modifies Slavin's Students Teams Achievement Division (STAD) method by using Newton's (2010), terminology namely Students Helping Students Technique "SHS". The idea behind the SHS Technique is to empower the students who has more knowledge or those who are fast learners to be the teacher's assistant for the teaching in the peer or team. As the basic principle of effective learning is the less number of the students the more active they are in learning. In line with Koenig (2015), that the students generally preferred small course because they feel the sense of community is more confortable.

Newton (2010), defines characteristic of helper in "Students Helping Students" as "in some ways more knowing, more experienced, and more capable in a designated area of service than the others". The helpers are the students who have been trained and appointed by campus authority to offer educational services to their peer.

The writer redefines Students Helping Students Technique is a teaching technique that involves or empowers the students in teaching process. According to Park (2003), the Students who are engaged actively in the learning process tend to comprehend the lesson more. The typical students who will be empowered are those who are more experienced, more knowing, more capable and faster in learning. Their roles are to do some helping, facilitating, mentoring, advising, instructing, educating, aiding, assisting, leading, and counseling the other students who lack knowledge or motivation.

This research aims to measure the effectiveness of Students Helping Students Technique in students' English grammar achievement in experimental group after the treatment.

The writer composes SHS Technique into eight major components adapted from Slavin's STAD (1995): Opening, Class Presentations, Assessment, teams/peer, teacher assistance, quizzes, individual improvement, scores and team recognition. Opening, In the opening, the teacher does greeting and small talking to the students; also ask their English background whether they have studied the material that will be taught. This aims to do the first identification for potential students that will be set as helpers. Class Presentation, The teacher presents the lesson to the students by using teaching media. Assessment, In this section, the teacher gives questions to the students either written or spoken. This aims to measure the individual comprehension about the materials. For those students who actively answer the questions correctly will be separated from others, they are potentially become helpers. Teams/peer, The number of students in group is not determined. The more students understand the teacher's presentation the more helpers will be set and the team will be smaller. Then, the teacher makes several groups or peers. 
Each helper is responsible to his/her members to make them have the same comprehension as does the helper. The teacher provides group worksheet to work on together and individual worksheet to measure the individual comprehension. The teaching activities in the group is applied by the helper under the teacher supervision. The students who has already understood the lesson will help the students who has not yet. Teaching Assistance, After that, the teacher visits each group to assist and motivate the helpers in doing their teaching. The teacher also may assist the members of the team if it is needed. Quizzes, Then, the students take individual quizzes. The helpers are not permitted to help their team during the quizzes. This makes sure that every student is individually responsible for knowing the material. Individual Improvement Score, The idea behind the individual improvement scores is to give each student performance goal that the student can reach, but only if she/he works harder and performs better than in the past. Team Recognition, Teams may earn certificates or other rewards if their average scores exceed a certain criterion. SHS Technique is in accordance with the principles of CL namely positive independence, in which each team can succeed only if all members succeed. Face to face promotive interaction, during which students assist and support each other's effort to achieve. Individual accountability refers to the fact that in SHS Technique, the team's success depends on the team members in working together and making sure that students will take without teammate's help. Interpersonal and small group is required to work cooperatively with others. Group processing, in which group reflect on how well team leader teach their members and how the group members being active asking the materials that they don't understand.

\section{METHODS}

This research was applied by using quantitative Quasi Experimental Design. The study employed experimental design with control group and experimental group. Both of the groups were given pre-test and post-test. The pre-test was administered to find out the students prior knowledge. After pretest was conducted, the control group was taught by traditional grouping technique and the treatment group was taught by using SHS Technique. The post-test was administered to find out the students' achievement after receiving treatment.

The populations of this research were all the second semester students of Nursing Department at Stikes Panakukang Makassar in academic year 2014/2015. It consists of two classes with the total population of 84 students.

The two classes are class (A) consisting of 43 students and class (B) consisting of 41 students. So, the researcher took the sample purposively. Each class was divided into two groups, the first group or class (A) was experimental group and the second group or class (B) was control group. There were 22 students in the first group categorized as experimental group and 20 students in the second group categorized as control group, resulting 42 total subjects of this research.

Grammar test administered to the both groups, experimental and control groups. The test was developed from student textbooks and authentic materials. The formats of the test were multiple choices since this format is quite familiar to the students, easy to administer, and it can be scored quickly. This GT was used to measure students' grammar achievement. It was administered to participants before treatment as pre-test, and after the treatment as post-test. GT consists of 30 items for pre-test which assesses the student's achievement in present tense, past tense, and future tense. While GT for post-test is also consists of 30 items on the same level as in pre-test. The purpose of the post test is to measure the grammar achievement of students in both groups.

This study was conducted in 6 (six) meetings and the duration of each meeting followed the teaching timetable of English class. The control group taught using the traditional grouping technique, while for experimental group engaged with cooperative learning using Students Helping Students Technique. All the tests or quizzes were identical for both groups.

The methods of analyzing the data from both experimental and control groups were calculated as follows:

$$
\begin{aligned}
& \text { A student score }=\frac{\text { The gained score }}{\text { The maximum score }} \times 100 \\
& \text { The gained scores of each student was } \\
& \text { converted to a set of score of maximum of }
\end{aligned}
$$


100. The classification of the students' score were as follows (Depdiknas, 2006).

95 to 100 is classified as excellent

85 to 94 is classified as very good

75 to 84 is classified as good

65 to 74 is classified as fairly good

55 to 64 is classified as fair

35 to 54 is classified as poor

00 to 34 is classified as very poor

The formula of calculating the percentage of students' score as follows (Sudjana, 2010).

Calculating the mean score, standard deviation, frequency table and t-test between grammar achievement of the experimental group and control group by using SPSS 18.0 evaluation version program for windows.

After administering questionnaire to the students in experimental group, the questionnaire responses were calculated into percentage. The researcher used the percentage technique using the following formula (Sudjana, 2010).

\section{RESULTS AND DISCUSSION}

\section{Result}

The grammar achievement of the students in both experimental group and control group improved as drawn in their pre-test and post-test result. But, the performance of the students of experimental group was higher than the students in control group. The (table 1) shows the mean score of post-test is 70.272 and the standard deviation is 10.112 . While the mean score of the students in control group is 58.800 and the standard deviation is 9.785 . But in order to claim that there are significant improvements in experimental group, by thoroughly examining the result of the paired samples statistic. (table 2) The value of significance is at .000 which is lower than 0.05 $(.000<0.05)$, it means the improvement of the students' performance in experimental group is significant after the experimentation process.

The result of independent sample t-test (table 3) reveals that $t$-value is higher than $\mathrm{t}$ table (2.021). Since t-value is higher than ttable $(3.272>2.021)$ at (40) df. The comparison of Post-test in Control and Experimental group shows on (chart 1). Mean Score in Control group 58.800 while in Experimental group 70.272. It means the improvement of experimental group is highly significant than the control group. Therefore, the alternative hypothesis ( $\mathrm{H} 1)$ is accepted and null hypothesis (H0) is rejected.

The application of cooperative learning SHS Technique increase students' participation in class activities and students' social interdependence (chart 2). Moreover, this SHS Technique strategy in learning process is responded positively and the application is preferable since the answers of "agree" and "strongly agree" in questionnaire responds are higher in mean score which are $49.09 \%$ on agree and $44.85 \%$ on strongly agree.

Table 1. The rate percentage of Pre-test scores distribution in Control Group (CG) and Experimental Group (EG)

\begin{tabular}{ccccccc}
\hline & & & \multicolumn{2}{c}{ Pre-test CG } & \multicolumn{2}{c}{ Pre-Test EG } \\
\hline N. & Classification & Score & F & \% & F & \% \\
\hline 1 & Excellent & 95 to 100 & - & - & - & - \\
2 & Very Good & 85 to 94 & - & - & - & - \\
3 & Good & 75 to 84 & - & - & - & - \\
4 & Fairly Good & 65 to 74 & - & - & - & - \\
5 & Fair & 55 to 64 & 2 & 10.00 & 2 & 9.09 \\
6 & Poor & 35 to 54 & 15 & 75.00 & 10 & 45.45 \\
7 & Very Poor & $00-34$ & 3 & 15.00 & 10 & 45.45 \\
\hline \multicolumn{2}{r}{ In Total } & & $\mathbf{2 0}$ & $\mathbf{1 0 0}$ & $\mathbf{2 2}$ & $\mathbf{1 0 0}$ \\
\hline
\end{tabular}

The tables 1 . above show that none of the students reach level of excellent, very good, good and fairly good in both control group (CG) and experimental group (EG). In level of poor, there are 15 students $(75.00 \%)$ in $\mathrm{CG}$ and 10 students $(45.45 \%)$ in EG who reached this level, 
while level of very poor there are 3 students $(15.00 \%)$ in CG and 10 students $(45.45 \%)$.

Table 2. The rate percentage of Post-test scores distribution in Control Group (CG) and Experimental Group (EG)

\begin{tabular}{ccccccc}
\hline & & & \multicolumn{2}{c}{ Post-Test CG } & \multicolumn{2}{c}{ Post-Test EG } \\
\hline No & Classification & Score & F & \% & F & \% \\
\hline 1 & Excellent & 95 to 100 & - & - & - & - \\
2 & Very Good & 85 to 94 & - & - & 4 & 18.18 \\
3 & Good & 75 to 84 & 2 & 10.00 & 3 & 13.64 \\
4 & Fairly Good & 65 to 74 & 1 & 5.00 & 6 & 27.27 \\
5 & Fair & 55 to 64 & 11 & 55.00 & 9 & 40.91 \\
6 & Poor & 35 to 54 & 6 & 30.00 & 0 & 0.00 \\
7 & Very Poor & $00-34$ & 0 & 0.00 & 0 & 0.00 \\
\hline \multicolumn{2}{r}{ In Total } & $\mathbf{2 0}$ & $\mathbf{1 0 0}$ & $\mathbf{2 2}$ & $\mathbf{1 0 0}$ \\
\hline
\end{tabular}

Table 2 illustrates that in students' posttest, the highest score is in good level with 2 students $(10.00 \%)$ in control group, while experimental group the highest level is very good with 4 students (18.18\%). In level of good, students in experimental group still did better with 3 students $(13.64 \%)$. Then, 1 student $(5.00 \%)$ in CG and 6 students $(27.27 \%)$ in EG who scored fairly good, Meanwhile in the level of fair which is also the biggest distribution of frequency, there are 11 students $(55.00 \%)$ in CG and 9 students $(40.91 \%)$ in EG. The next level which is classified as poor level, there are 6 students $(30.00 \%)$ in control group but in experimental group there aren't any students in this level. There aren't any students in both control group and experimental group classified as very poor level.
The statistical data analysis on this study applies several procedures such as Homogeneity Test of Samples, Normality Test of the Data, Classification of Students' Score, Mean Score and independent Sample t-test. The Homogeneity Test of the Samples. Levene's test is used to see whether the data is homogenous (Sugiono, 2010). In analyzing the homogeneity of the sample, researcher used the pre-test result of both experimental and control groups. The data is homogenous if the observed significance is greater than $5 \%$ at level of significance. If the observed significance is less than $5 \%$ at level of significance, it is categorized heterogeneous. This test is imperative to validate both the experimental and control groups are homogeneous, so that the two groups can be used as sample of the research.

Table 3: Test of Homogeneity of Variances

\begin{tabular}{llrrrrr}
\hline \multicolumn{5}{c}{ Test of Homogeneity of Variance } & & \\
\hline & & & & & \multicolumn{1}{c}{ Sig. } \\
Value & Levene Statistic & df1 & df2 & \\
& Based on Mean & .045 & & 1 & 40 & .833 \\
& Based on Median & .135 & 1 & 40 & .715 \\
& Based on Median and with & .135 & 1 & 35.484 & .715 \\
adjusted df & & & & \\
& Based on trimmed mean & .062 & 1 & 40 & .805 \\
\hline
\end{tabular}

Based on the table 3, it can be seen the significance (sig.) shows the result 0.833 . If the value of significance is greater than $0.05(0.833$ $>0.05$ ), it means that variances of two groups are homogeneous.
Test of normality is used to find out whether the data is coming from normal or abnormal distribution. The data is distributed normally if the observed significance is greater than $5 \%$ at the level of significance $(p>a$, $\mathrm{a}=0.05$ ), and it is not distributed normally if 
observed significance is less than 5\% at the level of significance $(p<a, a=0.05)$. This part of the statistical analysis is the requirement analysis before the independent t-test is run. It is imperative for the data to be distributed normally before further analysis is conducted. The result of normality test is presented as follows:

Table 4: Normality Test

\begin{tabular}{llr}
\hline & \multicolumn{2}{c}{ Kolmogorov-Smirnov Test } \\
& \multicolumn{1}{c}{$\mathrm{N}$} & Value \\
\hline Normal Parameters, & Mean & 42 \\
\cline { 2 - 2 } & Std. Deviation & 40.9524 \\
Most Extreme & Absolute & 11.04084 \\
Differences & Positive & .113 \\
\multicolumn{2}{c}{ Negative } & .087 \\
Kolmogorov-Smirnov Z & -.113 \\
Asymp. Sig. (2-tailed) & .731 \\
a. Test distribution is Normal. & .659 \\
b. Calculated from data. & \\
\hline
\end{tabular}

The normality test with KolmogorovSmirnov on table 4 shows the post-test result; Significance is 0.659 . (0.659>0.05). Both of experimental and control group indicate greater than $5 \%(0.05)$ level of significance. Thus, the post-test data of experimental and control group was normally distributed so that, further statistical analysis can be continued.

The mean score and standard deviation of experimental group were computed to find the improvement of students' performance post the experiment. In order to have such data, paired sample t-test was run. Paired sample t-test is a kind of statistical test whose purpose is to obtain the significant difference between the pre-test and post-test of the same group, in this case it is the experimental group. The result of the test can be seen as follows:

Table 7. The mean and std. deviation of experimental group

\section{Paired Samples Statistics}

\begin{tabular}{llllrr} 
& & Mean & N & Std. Deviation & Std. Error Mean \\
\hline Pair 1 & Pre-test Experimental & 39.000 & 22 & 10.876 & 2.319 \\
& Post-test Experimental & 70.272 & 22 & 10.124 & 2.158 \\
\hline
\end{tabular}

Table 8. Result of paired sample statistic

Paired Samples Test

\begin{tabular}{|c|c|c|c|c|c|c|c|c|}
\hline & \multicolumn{5}{|c|}{ Paired Differences } & \multirow[b]{4}{*}{$\mathrm{T}$} & \multirow[b]{4}{*}{ Df } & \multirow{4}{*}{$\begin{array}{l}\text { Sig. (2- } \\
\text { tailed) }\end{array}$} \\
\hline & \multirow[b]{3}{*}{ Mean } & \multirow{3}{*}{$\begin{array}{c}\text { Std. } \\
\text { Deviation }\end{array}$} & \multirow{3}{*}{$\begin{array}{l}\text { Std. } \\
\text { Error } \\
\text { Mean }\end{array}$} & \multirow{2}{*}{\multicolumn{2}{|c|}{$\begin{array}{l}\text { 95\% Confidence } \\
\text { Interval of the } \\
\text { Difference }\end{array}$}} & & & \\
\hline & & & & & & & & \\
\hline & & & & Lower & Upper & & & \\
\hline Pair 1 before - after & -31.273 & 8.514 & 1.815 & -35.048 & -27.498 & -17.228 & 21 & .000 \\
\hline
\end{tabular}


Table above indicates that the mean score of pretest and post of the experimental group is different, that the post-test score is higher than the pre-test one. The mean of the pre-test is 39.000 (table 7) while the post-test scored 70.272, and in standard deviation of pretest is 10.876 , while the post-test scored 10.124. Yet further analysis is conducted to see whether such difference is significant.

The difference is claimed to be significant if the observed significance is lower than $5 \%$ at the level of significance. By thoroughly examining the result of the paired sample statistic, it can be seen that the observed significance is lower than $5 \%$. The value of the significance is at .000 (table 8) which is lower than $0.05(.000<0.05)$. Such result suggested that the improvement of the experimental group is significant after the experimentation process. Moreover, to answer the question of the research an independent sample t-test needed to be conducted at the next part.

Independent sample t-test was computed to find out the significance of two different unrelated groups which is the control and experimental group.

The result of the analysis will indicate whether or not the improvement between the control and experimental group after the treatment is significant. The improvement was proved to be significant if the t-observed is lower than $5 \%$ at level of significance. The result of the analysis is presented below:

Table 9. Mean and standard deviation of post- test of control and experimental group

\begin{tabular}{|c|c|c|c|c|c|c|}
\hline \multicolumn{7}{|c|}{ Group Statistics } \\
\hline & Group & $\mathrm{N}$ & & Mean & Std. Deviation & Std. Error Mean \\
\hline \multirow{2}{*}{$\begin{array}{l}\text { Post - test in EG } \\
\text { and CG }\end{array}$} & 1 & & 22 & 70.272 & 10.123 & 2.158 \\
\hline & 2 & & 20 & 58.800 & 9.785 & 2.188 \\
\hline
\end{tabular}

Table 10. Result of Independent T-Test

\section{Independent Samples Test}

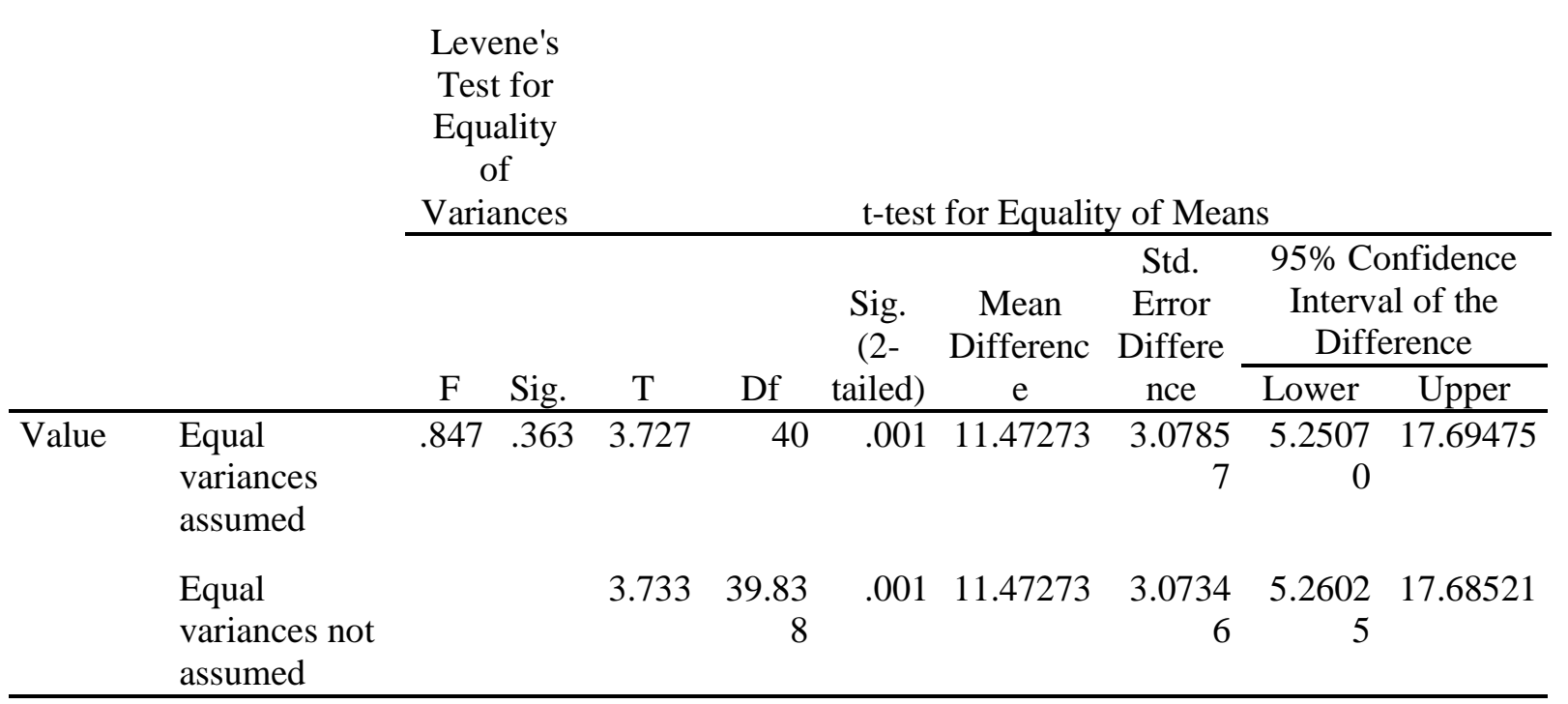

The table above shows that the mean score and standard deviation of the post-test of control and experimental group is different. The mean score of the control group is 58.800 while the experimental group scored 70.272. In order to know if such difference is significant, the independent sample t-test was run. The level of significance $(\alpha)$ value was 0.05 or $95 \%$ as the confidence interval of difference, and probability (p) was 0.001 . To make sure that 
there was significance difference between the two scores, the comparison should be made between the t-value which is higher than t-table (2.021). Since t-value is higher than $\mathrm{t}$-table $(3.272>2.021)$, it means that the null hypotheses (H0) is rejected. It indicates that the improvement of experimental group highly significant than the control group.

The grammar achievement of the students in both experimental group and control group improved as drawn in their pre-test and post-test result. But, the performance of the students of experimental group was higher than the students in control group. The (table 1) shows the mean score of post-test is 70.272 and the standard deviation is 10.112 . While the mean score of the students in control group is 58.800 and the standard deviation is 9.785 . But in order to claim that there are significant improvements in experimental group, by thoroughly examining the result of the paired samples statistic. (table 2) The value of significance is at .000 which is lower than 0.05 $(.000<0.05)$, it means the improvement of the students' performance in experimental group is significant after the experimentation process.

The result of independent sample t-test (table 3) reveals that $\mathrm{t}$-value is higher than $\mathrm{t}$ table (2.021). Since t-value is higher than ttable $(3.272>2.021)$ at (40) df. The comparison of Post-test in Control and Experimental group shows on (chart 1). Mean Score in Control group

58.800 while in Experimental group 70.272. It means the improvement of experimental group is highly significant than the control group. Therefore, the alternative hypothesis (H1) is accepted and null hypothesis (H0) is rejected.

\section{Discussion}

Cooperative learning STAD has been researched in many aspects of teaching such as Wiraningsih (2016), conducted the research on the Developing Speaking Skill through STAD. Ferina (2015), her research aimed to find a significant difference on students' achievement in reading comprehension taught using STAD and lecture method, Rahman and Syatroh (2015) conducted the research on The Analysis of STAD Used in Learning Practice of Translating and Interpreting, Sunarti (2012), conducted the research on the effectiveness of STAD to teach vocabulary viewed from students' English learning interest, Amin (2004), in her research on developing speaking performance through Cooperative Learning using STAD.

The above studies show how the teachers used Cooperative Learning through STAD from some ways methods and strategy. The writer finds that there are some obstacles faced by the teachers and students in learning English by using STAD So that, the writer conducted the research based on the problems faced especially in teaching grammar through STAD.

This research shows that the application of SHS Technique was effective in improving the grammar achievement of the students based on the T-test that the t-value is higher than $\mathrm{t}$ - table (2.021). Since $\mathrm{t}$-value is higher than t-table $(3.727>2.021)$, this means the improvement of experimental group is highly significant than the control group. Therefore, the alternative hypothesis (H1) is accepted and null hypothesis (H0) is rejected.

\section{CONCLUSION AND SUGGESTIONS}

The grammar achievement of the students in both experimental group and control group improved as drawn in their pre-test and post-test result. But, the performance of the students of experimental group was higher than the students in control group. The mean score of post-test is 70.272 and the standard deviation is 10.1123 . While the mean score of the students in control group is 58.800 and the standard deviation is 9.785 . The result of independent sample t-test reveals that $t$-value is higher than $\mathrm{t}$-table (2.021). Since t-value is higher than ttable $(3.272>2.021)$ at $(40) \mathrm{df}$. It means the improvement of experimental group is highly significant than the control group. Therefore, the alternative hypothesis (H1) is accepted and null hypothesis (H0) is rejected. This study proves that Cooperative Learning SHS Technique is better for English subject than Traditional Grouping Method (TGM). Therefore, teachers of English subject are highly suggested to use this SHS Technique to improve students' academic achievements. This study only examined the achievement in students' grammar but SHS Technique can be conducted to develop other language elements such as vocabulary or pronunciation also language skills such as reading, writing and speaking. The researcher would like to suggest to English lecturers of Stikes Panakukang Makassar to apply this SHS 
Technique in their teaching learning process because it has been proved that the result of Grammar Test has shown significant improvement.

\section{REFERENCES}

Amin F. (2004). Developing Speaking Performance through Cooperative Learning. Unpublished Thesis. UNM, Makassar.

PARK C. (2003). Engaging Students in the Learning Process: the learning journal. Journal of Geography in Higher Education, 27(2).pp11-19

Depdiknas. (2006). Standar Kompetensi SMA/MA, Kurikulum 2006. Jakarta: Dharma Bakti. Johnson

Johnson D.W. Johnson R.T. (1994). Positive Interpendence: key to effective cooperation. INR.

\section{Hertz-Lazarowiz \& N Miller (EDS) Interaction in Cooperative Learning: $\quad$ The Theoretical Anatomy of Group Learning (pp 174-199). Cambridge: Cambridge Press.}

Ferina F. (2015). STAD as a Strategy of Teaching Reading Comprehension in Junior High School. JEELS (Journal of English Education and Linguistics Studies),IAIN Kediri. 2(1).pp 21-43

Rahman A. and Syatroh I. (2015). The anylisis of Students' Team Achivement Devision (STAD) Used in Learning Parctice of Translating and Interpreting. ELTIN, Journal of English Language Teaching in Indonesia, 3(2).pp 72-84

Lynn K. \& Gretchen B. (2010). Grammar Matters. Teaching grammar in adult ESL Program. Cambridge: Cambridge University.
Martin (2015). Students Preferences for Small and Large Class Sizes. International Journal of Humanities and social Science, 5(1): 5-11

Newton F.B. (2010). Students Helping Students. Jossy Bass. Second Edition. USA: A Willey Imprint.

Schellekens P. (2007). The Oxford ESOL Handbook. Oxford: Oxford University Press.

Sharan S. \& Sharan Y. (1992). Group investigation: Expanding cooperative learning. New York: Teacher's College Press.

Slavin R.E. (1994). Cooperative learning: Theory, research and practice. 2nd Ed. Boston: Allyn and Bacon.

Subasini M \& Kokilavani B (2013). Significance of grammar in technical English. International Journal of English Literature and Culture, 1(3),pp 57-64.

Sudjana. (2010). Penilaian Hasil Belajar Mengajar, Bandung: Rosda Karya.

Woolfolk A. (2010). Educational psychology. $10^{\text {th }}$ Ed. Pearson Education, Inc

Wiraningsih V. (2016). Developing Speaking Skill Through STAD at Grade XI Students of SMA Negeri 8 Palu. $e$ Journal of English Language Te 